
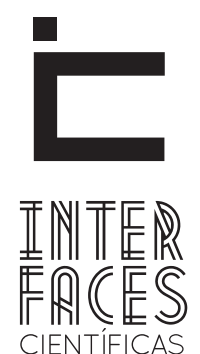

EDUCAÇÃO

ISSN IMPRESSO 2316-333X

E-ISSN 2316-3828

DOI-10.17564/2316-3828.2018v6n3p29-40

\title{
AUTORAIS PARTILHADAS NA INTERFACE CIDADE-REDES DIGITAIS
}

\author{
SHARED AUTHORS IN THECITY-DIGTAL NETWORKS INTERFACE \\ AUTORÍAS COMPARTIDAS EN LA INTERFAZCIUDAD-REDES DIGTALES
}

Edméa Oliveira dos Santos ${ }^{1}$

Felipe da Silva Ponte de Carvalho ${ }^{2}$

\section{RESUMO}

A conexão de celulares, tabletes e notebooks em rede possibilita novas formas de aprender e ensinar, fazendo com que a relação no processo de produção conhecimento seja tecido entre todos-todos. É nesse cenário sociotécnico emergente que a presente pesquisa-formação na cibercultura se situa. A pesquisa em tela aconteceu com cursistas da disciplina de "Informática na Educação" do curso de Pedagogia UERJ/CEDERJ/UAB a distância pela plataforma Moodle, em 2017.1. Nessa disciplina, arquitetamos aulas que servem de disparadores de narrativas, vídeos, sons e imagens produzidos com os/pelos cursistas. Neste relato de pesquisa, trouxemos a "Aula 3 - Práticas pedagógicas ubíquas: (re)criando e (re)pensando os espaçostempos da formação na cidade!", que é inspirada na docência interativa em ambiências híbridas para a manifestações de autorias e cujo objetivo é ampliar o repertório do(a)s cursistas em relação ao espaçostempos formativos online via dispositivos móveis. Essa aula está composta por fórum de discussão no Moodle, artigo científico, atividade prática de produção autoral na interface cidade-redes digitais e seu compartilhamento em grupos de discussão pela rede social Facebook. Do cotidiano pesquisado emergiu a noção de práticas de autorias partilhadas, que pode ser compreendida como uma ação de autorização do sujeito no fazer por si mesmo (autoria) e de compartilhar a autoria para um grupo (partilha). Essa prática possibilita cada um trocar "algo que sei e que criei" na rede de participantes da turma.

\section{PALAVRAS-CHAVE}

Multirreferencialidade. Docência Onl-ine. Autoria. Pesquisa-Formação na Cibercultura. 


\section{ABSTRACT}

Connecting mobile phones, tablets and notebooks on the net enables new ways of learning and teaching, making the relationship in the knowledge production process woven among everyone. It is in this emerging socio technical scenario that the present research-training in cyberculture is situated. The on-screen research happened with students from the subject of "Informatics in Education" of the course of Pedagogy UERJ / CEDERJ / UAB the distance by the platform Moodle, in 2017.01. In this discipline, we designed classes that serve as triggers for narratives, videos, sounds and images produced with the / by the students. In this research report, we have brought "Class 3 - Ubiquitous pedagogical practices: (re) creating and (re) thinking spaces of training in the city!", Which is inspired by interactive teaching in hybrid environments for authorship manifestations, and whose The goal is to broaden the repertoire of the trainees in relation to the formative spaces online via mobile devices. This class is composed by discussion forum in Moodle, scientific article, practical activity of authoring production in the interface city-digital networks and its sharing in groups of discussion by the social network Facebook. The notion of shared authorship practices emerged from the researched daily, which can be understood as an authorization action of the subject in doing for himself (author) and sharing the authorship for a group (sharing). This practice enables each to exchange "something I know and create" in the network of class members.

\section{KEYWORDS}

Multireferentiality. Online Teaching. Authorship. Research-Training in Cyberculture.

\section{RESUMEM}

La conexión de teléfonos móviles, tabletas y portátiles en red posibilita nuevas formas de aprender y enseñar, haciendo que la relación en el proceso de producción conocimiento sea tejido entre todos-todos. Es en ese escenario sociotécnico emergente que la presente investigación-formación en la cibercultura se sitúa. La investigación en pantalla tuvo lugar con integrantes de la disciplina de "Informática en la Educación” del curso de Pedagogía UERJ/ CEDERJ/UAB a distancia por la plataforma Moodle, en 2017.01. En esta disciplina, construimos clases que sirven de disparadores de narrativas, vídeos, sonidos e imágenes producidos con los/por los alumnos. En este relato de investigación, traemos la "clase 3 - Prácticas pedagógicas ubicuas: (re) creando y (re) pensando los espacios de la formación en la ciudad!", Que es inspirada en la docencia interactiva en ambientes híbridos para las manifestaciones de autorías, y cuyo objetivo el objetivo es ampliar el repertorio de los cursistas en rela- ción a los espaciostempos formativos en línea a través de dispositivos móviles. Esta clase está compuesta por foro de discusión en Moodle, artículo científico, actividad práctica de producción autoral en la interfaz ciudad-redes digitales y su compartición en grupos de discusión por la red social Facebook. De la cotidiana investigada surgió la noción de prácticas de autoría compartida, que puede ser comprendida como una acción de autorización del sujeto en el hacer por sí mismo (autoría) y de compartir la autoría para un grupo (compartir). Esta práctica permite a cada uno intercambiar "algo que sé y que he creado" en la red de participantes de la clase.

\section{PALABRAS-CLAVE}

Multirreferencialidad. Docencia en línea. Autoría. Investigación-Formación en la Cibercultura. 


\section{ENTRELAÇAMENTOS INICIAIS}

Novas formas de comunicar, interagir, habitar e compartilhar sentidos estão sendo constituídas nos espaçostempos da interface cidade/redes digitais, principalmente com a difusão dos smartphones. Essas práticas e experiências dão sentido e forma ao que denominamos de cibercultura, que é nossa cultura contemporânea e que, na atualidade, se caracteriza pela ubiquidade da mobilidade e da conectividade (SANTOS, 2012, on-line). Esse contexto sociotécnico que estamos vivenciando, seja como ator ou autor, traz possibilidades para pensarmos alternativas de práticas educativas que extrapolam os espaçostempos das plataformas de educação on-line.

Em nossas pesquisas (CARVALHO, 2015; SANTOS et al., 2016), adotamos a abordagem da educação on-line, que é concebida tendo a cibercultura como inspiração potencializadora das práticas pedagógicas, visando promover a aprendizagem crítica e colaborativa, a (co)autoria do aprendente, a autonomia e a criatividade na aprendizagem por meio de uma mediação docente voltada para interatividade e partilha. Nesse sentido, na próxima seção discutimos "os desafios e os princípios da docência interativa" na cibercultura (SILVA, 2009a; 2009b) atrelados às discussões sobre autoria (BACKES, 2012).

Optamos pela epistemologia da "multirreferencialidade" (ARDOINO, 2012, p. 87) para pensar esta pesquisa, o que possibilita ao pesquisador um olhar heterogêneo de seu contexto de pesquisa, pois "propõe-se explicitamente uma leitura plural de tais objetos, sob diferentes ângulos e em função de sistemas de referências distintos"; em que o conhecimento construído é um conhecimento inacabado, da falta, tecido como uma atividade artesanal de bricolagem; que nos possibilita compreender os sujeitos como produtores de cultura e assim pensar uma formação para além da disciplinarização.

A multirreferencialidade transforma práticas em práxis, pois estão envoltas nas problemáticas do sujeito que se transforma por meio de suas práticas, agindo sobre o mundo e se transforma também pela política, pois as ações no mundo são políticas. O político por definição é práxis, como lembra Berger (2012, p. 27). Em nossa ação educativa, operacionalizamos a multirreferencialidade principalmente por meio da autorização. A noção de autorização é a capacidade do sujeito fazer-se autor; implica na construção de sua própria autoria. Para isso acontecer, é preciso reconhecer o outro em suas complexidades e incompletudes, pois como diz Macedo (2013, p. 94), “o processo de autorização requer o outro, sabendo-se que se autorizar deriva do latim auctor, aquele que acrescenta e funda".

Apresentamos, partindo desse pressuposto epistemológico, nosso referencial metodológico, que é a "pesquisa-formação na cibercultura" (SANTOS, 2014), em que o fazer pesquisa na cibercultura está articulado à docência. De acordo com essa abordagem metodológica, nós, docentes-pesquisadores, atuamos como propositores de práticas e situações educativas que levam os participantes a viverem processos formativos autorais e a partilhar experiências e narrativas de si.

As proposições dos docentes-pesquisadores fundamentam-se na noção de "dispositivo" de Ardoino (2003, p. 80), que é a "organização de meios materiais e/ou intelectuais, fazendo parte de uma estratégia de conhecimento de um objeto", ou seja, dispositivos disparadores de dados da pesquisa: narrativas, imagens, textos, vídeos, som. Cabe salientar que as imagens e as narrativas apresentadas neste artigo foram autorizadas pelos cursistas da disciplina.

De nossa pesquisa-formação na cibercultura emergiu a noção de "práticas de autorias partilhadas", que pode ser compreendida como uma ação de autorização do sujeito no fazer por si mesmo (autoria) e de compartilhar a autoria para um grupo (partilha). Essa prática possibilita cada um trocar "algo que sei e que criei" na rede de participantes da turma.

Nas Tessituras Finais, tecemos reflexões e apontamentos proporcionados pela vivência e experiência no cotidiano dessa pesquisa. Fazendo isso, não estamos querendo produzir uma receita a ser seguida, mas sim queremos repensar as nossas próprias práticas como docentes-pesquisadores. 


\section{DOCÊNCIA INTERATIVA E AMBIÊNCIAS HÍBRIDAS PARA A MANIFETAÇ̃̃O DE AUTORIA}

Partimos do pressuposto que a docência na cibercultura deve buscar: fomentar, potencializar e provocar situações de aprendizagem criadoras; oportunizar a partilha de múltiplas experiências e vivências com os estudantes no aprender-fazendo; propor atividades formativas que explorem produção de imagens, textos, vídeos, histórias em quadrinhos, animações, jogos; e usar os conteúdos criados pelos aprendentes nas práticas educativas (debates em sala de aula, no fórum de discussão etc.).

Para pensar a docência on-line, partimos dos desafios e princípios da "docência interativa" de Silva (2009a; 2009b) esquematizados na Figura 1:

Figura 1 - Docência interativa na cibercultura

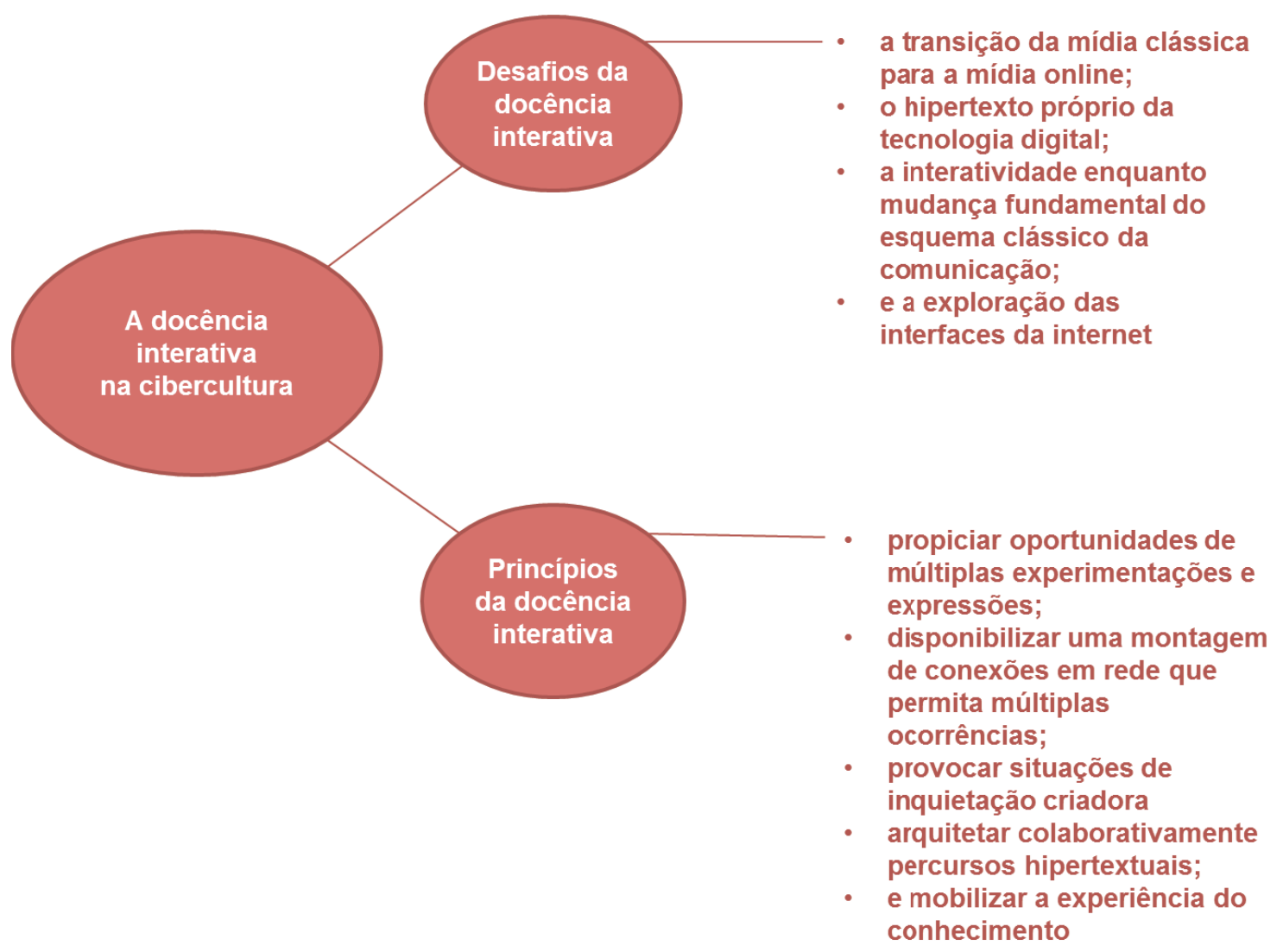

Fonte: Adaptado do referencial de Silva (2009a; 2009b). 
Partimos do pressuposto, também, que a docência na cibercultura deve buscar promover a autoria. Backes (2012) identifica "três manifestações de autoria":

Pré-autoria, na qual as narrativas pós-leitura de referenciais teóricos seguiam a lógica da semelhança e concordância com o texto lido, ou com o relato do colega;

A autoria transformadora, na qual já se percebem posicionamentos críticos por parte dos alunos, bem como uma relação direta do conhecimento construído e os novos elementos do viver;

$E$, finalmente, a autoria criadora, no qual o aluno se autoriza, de forma criativa, mediante certo deslocamento, uma espécie de inversão e modificação das representações, para dar passagem ao novo, promovendo, dessa forma, diferença na rede de relações estabelecida com o grupo.

Esses princípios e desafios da docência on-line e as concepções de autoria transformadora e criadora, nos ajudaram a pensar o desenho didático das aulas, con- forme discutiremos na próxima seção, na "Aula 3 - Práticas pedagógicas ubíquas: (re)criando e (re)pensando os espaçostempos da formação na cidade!". Essa aula também foi pensada a partir da noção de ambiências híbridas (CARVALHO, 2015), que visam possibilitar o cursista a interagir, discutir com o coletivo, manipular e criar seus próprios conteúdos/artefatos, convidar o outro para dialogar e colaborar com o produto criado, além de compartilhar a (co)autoria em rede. As ambiências híbridas são pensadas para integrar três pilares, representados na Figura 2, levando-se em consideração:

As fontes de informações (para situar a temática, prática e concepção que faz parte da aula ou atividade);

Os sistemas de autoria (para a manifestação de autorias nas ações de aprendizagem individual/dupla/grupo);

E as redes sociais digitais (para compartilhar, discutir e tecer o conhecimento mais aberto e informal, proporcionando a tessitura dos atos de currículo para além dos espaçostempos institucional).

Figura 2 - Pilares da ambiência híbrida

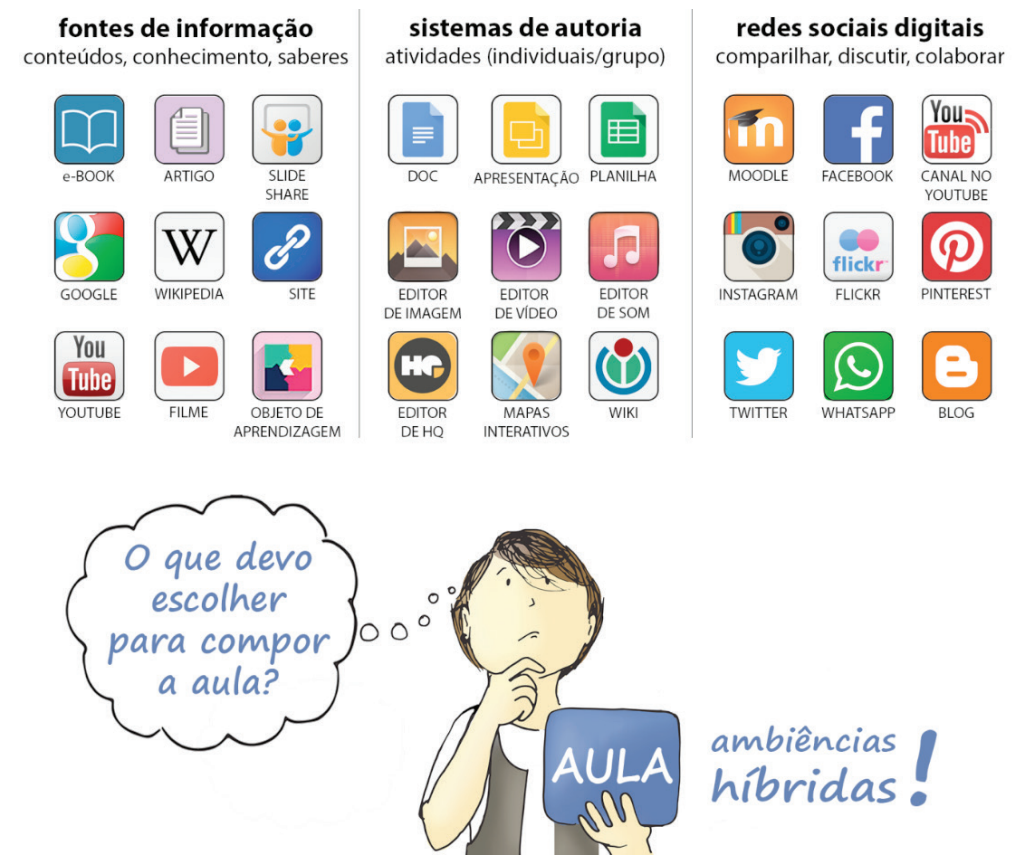

Fonte: Carvalho (2015) 
Os três pilares inspiram a docência à fazercriarsuas práticas educativas, seja para oportunizar momentos de conversas que produzam a reflexão e a discussão, com a participação coletiva de todos os envolvidos, seja para convidar o aprendente à (co)autoria; isso é, para que ele cocrie algo com os colegas, para que as ideias possam ser debatidas, confrontadas, tecidas e aprimoradas, com vistas a ir além da condição de consumidor de conteúdos, passando também a criar, disponibilizar, discutir e compartilhar suas autorias em rede.

Ressaltamos que os produtos gerados pelos praticantes devem ser compartilhados com todos da turma, seja pelos ambientes virtuais de aprendizagem (que também são espaços sociais) como o Moodle, seja pelos sistemas de redes sociais (que também são sistemas de autoria em potencial), como o Facebook, Twitter, WhatsApp, Instagram entre outros.

Ao compartilhar uma postagem, um documento, um vídeo ou uma reflexão de sua autoria ou de seu grupo, suas reflexões e hipóteses temporárias são externalizadas, o que possibilita o outro compreender o seu inacabamento e, assim, complementar ou confrontar ideias que podem desequilibrar e desconstruir as certezas provisórias do sujeito, levando-o a um novo estado de reflexão que, eventualmente, resulta em aprendizado; além de potencializar o trabalho participativo e coletivo, ampliando as experiências entre os sujeitos desse processo.

Quando a autoria é postada os sistemas de redes sociais, a produção não fica restritas ao espaço institucional, podendo também se valer das redes sociais de familiares e amigos, que podem propagar e até viralizar, contribuindo para transformar o mundo virtual-presencial em que habita.

\section{PENSAR E FAZER A PESQUISA ACADÊMCIA EM TEMPOS DE CIBERCULTURA}

O cotidiano dessa pesquisa-formação na cibercultura aconteceu na disciplina de "Informática na Educação”, que é ofertada no $4^{\circ}$ período do curso de Pedagogia UERJ/CEDERJ/UAB a distância. 0 curso é estruturado e organizado pela plataforma digital Moodle. $O(A) s$ participantes da pesquisa foram o(a)s cursistas dos polos Magé, Belford Roxo e Três Rios, que são municípios situados no estado do Rio de Janeiro.

A pesquisa-formação na cibercultura, segundo Santos (2014), é um método de pesquisa que busca promover a autoria docente na interface com o ato de pesquisar pelas redes digitais. Tem como disparador inicial a implicação da docência com a sua própria prática, da qual emerge problematizações, questões de estudos, dilemas e experiências formativas. A atualização do método, portanto, acontece a partir da triangulação: implicação docente, pesquisa e autoria.

Desse modo, o método proposto parte de alguns pontos caros (SANTOS, 2014): não há pesquisa-formação na cibercultura sem imersão, mergulho, vivência e experiência on-line; não há como fazer pesquisa-formação desarticulada do contexto da docência; educação on-line não é uma mera evolução das práticas massivas de EAD; e não se separa os contextos educativos das cidades e seus equipamentos culturais (escolas, universidades, movimentos sociais, museus, organizações, eventos científicos, demais).

Partimos do pressuposto que o docente-pesquisador na cibercultura deve compreender os sujeitos da pesquisa como praticantes culturais; atuar promovendo proposições de práticas educativas; usar diversos meios para possibilitar a tessitura de autorias em rede; se inspirar em fenômenos ciberculturais; ter uma participação ativa no cotidiano pesquisado; e promover partilhas (NÓVOA, 2003) de práticas, vivências, saberes e experiências que fomentem a produção do conhecimento. "Se é verdade, como diz Paulo Freire, que é o diálogo que nos faz pessoas, sublinho agora que é a partilha com os colegas que nos faz educadores" (NÓVOA, 2003, p. 8).

Nesta pesquisa, propomos a "Aula 3 - Práticas pedagógicas ubíquas: (re)criando e (re)pensando os espaçostempos da formação na cidade!”, exposta na Figura 3, que tem as seguintes intencionalidades:

Discutir os conteúdos abordados no artigo "Educação e Cibercultura: aprendizagem ubíqua no currículo da disciplina de Didática” pelo fórum da platafor- 
ma Moodle. A opção pelo meio de comunicação fórum de discussão parte da necessidade de abrir conversas mais densas e mais aprofundadas em relação à temática proposta para discussão. Calvão e et al (2014) falam que o fórum de discussão é um meio de conversação assíncrono para a discussão entre muitos interlocutores que trocam mensagens de texto elaboradas, organizadas em tópicos;

Produzir um conteúdo autoral (individual) sobre a cidade onde mora, que pode ser um monumento, uma prática cultural (feira, roda de capoeira em roda pública, grupo de seresta etc.), um ponto de interesse geográfico (morro, rios, cachoeira, trilha etc.), do meio ambiente de onde mora (animal típico, denunciar um problema, dengue, desmatamento, reflorestamento etc.), um evento (exposição, congresso, teatro, inauguração etc.), etc. etc. etc. 0 conteúdo pode ser produzido no formato de vídeo, fotografia ou texto com imagem/vídeo, e deve ser compartilhado no grupo da disciplina pelo Facebook.

Figura 3 - Aula 3 - Práticas pedagógicas ubíquas: (re)criando e (re)pensando os espaçostempos da formação na cidade!

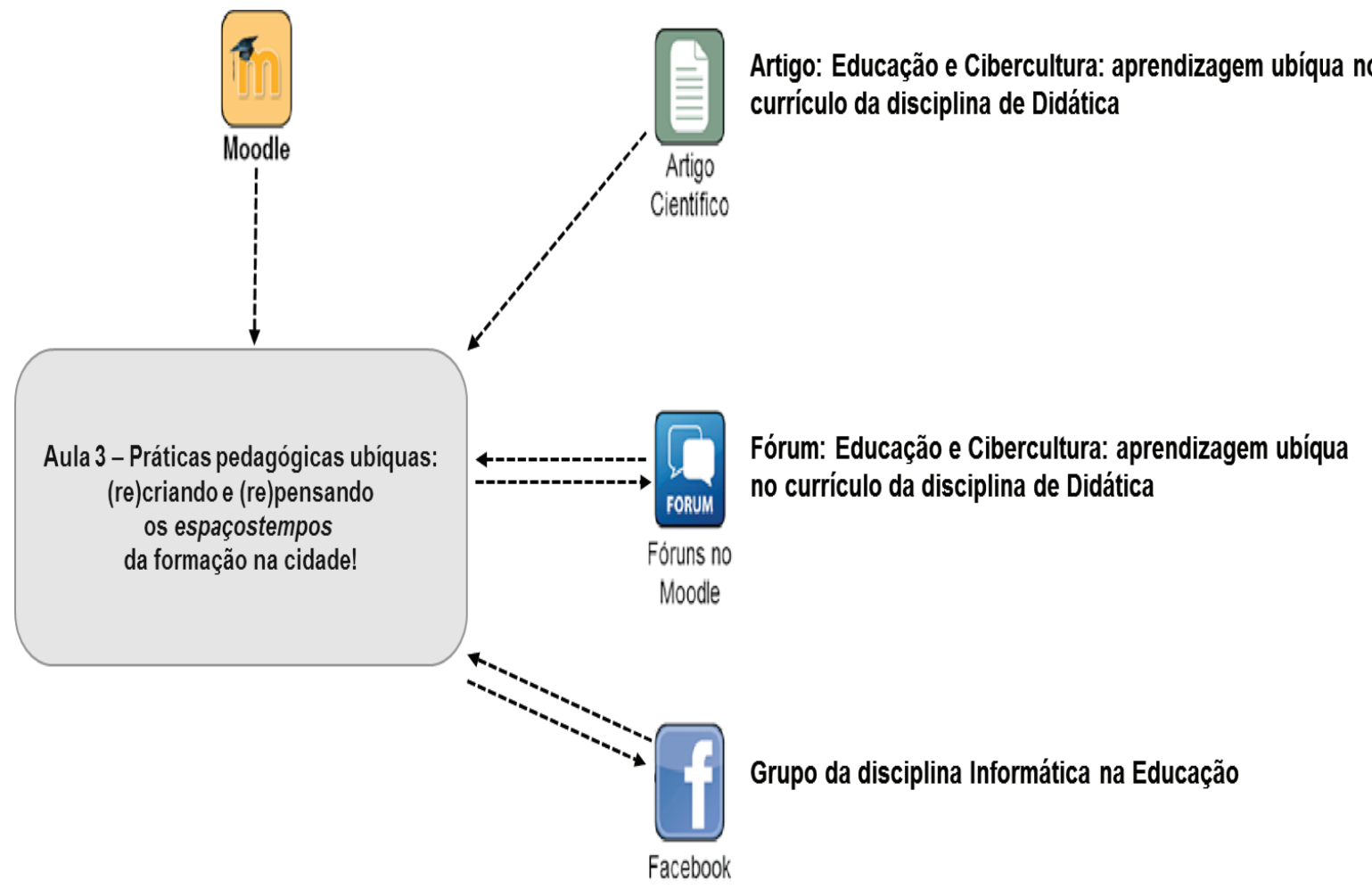

Fonte: Elaborado pelos autores. 
O objetivo principal dessa aula é ampliar o repertório do(a)s cursistas em relação ao espaçostempos formativos on-line. Para alcançar esse objetivo, acionamos os dispositivos de pesquisa: fórum de discussão pelo Moodle, artigos científicos, grupo pelo Facebook e intervenção na cidade com o uso de celulares conectado em rede. 0 propósito dessa aula é fazer os cursistas trazerem à superfície aquilo que produz sentido nos lugares que habitam, conforme relatamos na seção a seguir.

\section{PRÁTICAS DE AUTORIAS PARTILHADAS: COMPREENDENDO A FORMAÇÃO EM REDE}

Para chegar na noção que emergiu do cotidiano desta pesquisa, aqui denominada "práticas de autorias partilhadas", tecemos nossas análises em função de duas produções dos cursistas: a partilha de opiniões e posicionamentos dos cursistas sobre um assunto em discussão na turma; e a partilha das autorias dos cursistas pelo grupo no Facebook no qual cada um fez narrativas de si a partir do que produz sentido e significação no cotidiano vivido. Compreendemos as opiniões, os posicionamentos e as narrativas de si, manifestadas nas autorias dos cursistas, a partir da discussão que Backs (2012) faz sobre o processo de autoria e a partir da discussão de partilha em Nóvoa (2003).

$\mathrm{Na}$ primeira parte da Aula 3, solicitamos aos cursistas a leitura do artigo disponibilizado no Moodle - "Educação e Cibercultura: aprendizagem ubíqua no currículo da disciplina de Didática" - e que, a partir dessa leitura, trouxessem suas impressões, inquietações e problematizações. Nesse contexto, o cursista Tiago opinou sobre o papel do professor em tempos de cibercultura: "o professor como agente de transformação, deve provocar situações de inquietação e pensamento crítico por parte dos alunos". A fala desse cursista nos remete à problematização que Silva (2009) faz em relação à docência interativa na cibercultura, que deve propiciar aos formandos a oportunidade de múltiplas ex- perimentações, provocar situações de inquietação criadora e mobilizar experiência do conhecimento (SILVA, 2009).

O cursista Tiago salientou, ainda, que o "docente deve se comprometer com uma gestão que possibilite oportunidades múltiplas de experiências, dentro e fora do ambiente escolar". Essa narrativa se aproxima da noção de pré-autoria (BACKS, 2012), dado que a opinião do cursista está relacionada ao pensamento dos autores lidos naquela aula, estando em concordância, semelhança e aproximação à expressão do pensamento daqueles autores.

Na segunda parte da Aula 3 propusemos aos cursistas a produção de um conteúdo, a ser compartiIhado no grupo da disciplina pelo Facebook, sobre a cidade em que mora. As três publicações discutidas a seguir são produtos dessa atividade.

Figura 4 - Parque de Madureira

\section{Tiago Santos \\ $10 \mathrm{~h}$}

O Parque de Madureira é o terceiro maior parque público do estado, e possui uma área que se extende por cinco bairros, ele é um espaço de interação social da comunidade ao seu redor.

O espaço público em questão é totalmente inclusivo e sustentável, possuidor de uma área de aproximadamente 450 mil metros quadrados. Ele possui espaços destinados a esporte e lazer dos mais diferentes tipos, e em relação a multiculturalismo e cibercultura, ele abriga um prédio chamado "Nave do Conhecimento", que se destina a estes fins. Sejam bem vindos, e nos encontramos lá.

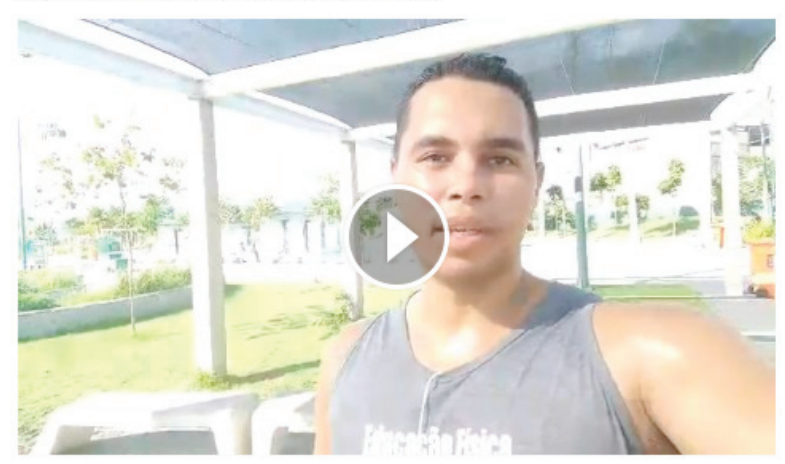

Fonte: Grupo disciplina Informática na Educação Link do vídeo: <https://www.facebook.com/ groups/179086744563938/permalink/17993328237 $17410 />$ 
Figura 5 - Panorâmica Parque Madureira

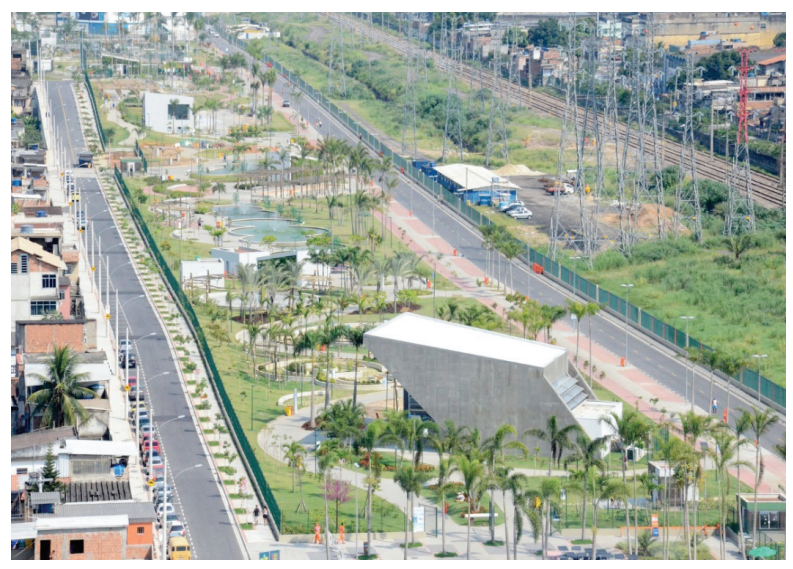

Fonte: Instituto Pinheiro (2017).

Por meio de um selfie-vídeo, o cursista Tiago mostrou os espaçostempos de produção de sentido no cotidiano por ele vivido, revelando as ambiências que compõem o Parque Madureira, cujo nome faz referência ao bairro onde o cursista mora (retratado nas Figuras 4 e 5), situado no subúrbio do município do Rio de Janeiro-RJ e que é um dos legados das Olimpíadas Rio 2016. Conforme destacado pelo cursista, há áreas para esportes e lazer, como também o projeto Naves do Conhecimento que "visa a democratização do acesso à informação e ao conhecimento de novas formas de aprendizagem em ambientes colaborativos" (O PROJETO..., 2017).

Já na publicação retratada na Figura 6, a cursista Claudiene relatou a transformação da rua principal do município de Magé (localizado na região metropolitana do estado do Rio de Janeiro) em um espaço cultural utilizado para realizar feira do livro, apresentações populares etc.
Figura 6 - Magé: espaço cultural

Claudiene Soares

Olá pessoal, gostaria de compartilhar com vocês uma rua principal de Magé que foi transformada num espaço cultural, onde já aconteceram várias apresentações, eventos, feiras e outros. Hoje esse espaço é conhecido como o " Calçadão de Magé" que se localiza na Rua Dr. Siqueira, centro. O espaço ficou super bacana!!!!

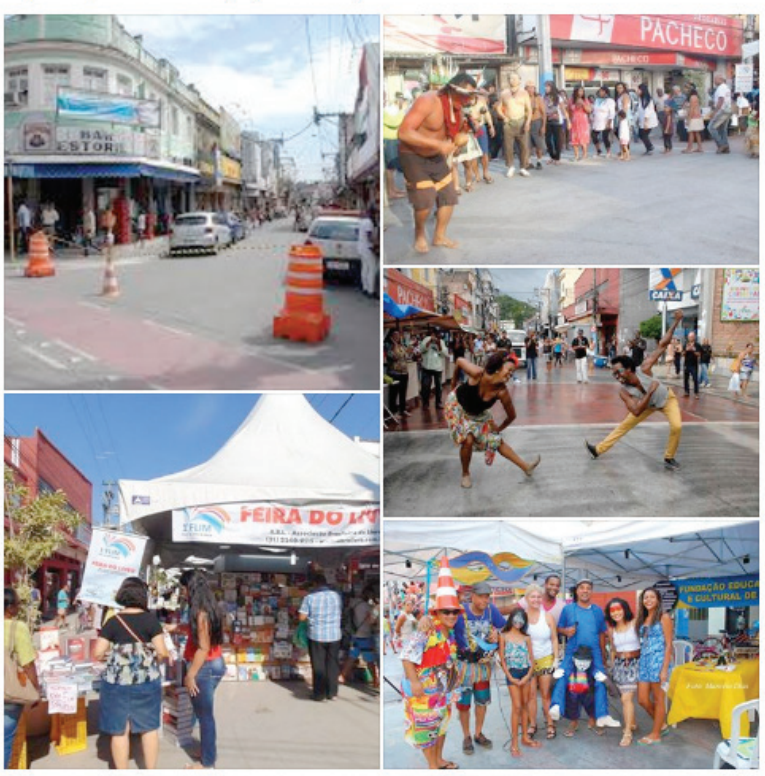

Fonte: Grupo disciplina Informática na Educação (16/04/2017).

Na publicação apresentada na Figura 7, a cursista Fernanda abordou os “100 anos do Quilombo da Maria Conga”, que também aconteceu no município de Magé, local onde se situa o quilombo. Vale ressaltar que, recentemente, os moradores da região produziram o documentário “Maria Conga - Orgulho de ser quilombola3", que fala um pouco da história da escrava Maria, fundadora do quilombo.

3 Disponível em: https://www.facebook.com/mukuiunzambi/videos/1081733165173589/ 
Figura 7 - Magé: 100 anos do Quilombo da Maria Conga

Fernanda Paulo Luzorio da Silva

14 de abril às 14:44

Olá, meu nome é Fernanda Luzorio, moro na Cidade de Magé na baixada, meu município é referência histórica no Estado do Rio de Janeiro, porém pouco conhecido. Aconteceu na última semana um evento para comemorar os 100 anos do Quilombo da Maria Conga, que foi o primeiro da baixada a ser reconhecido pela Fundação Cultural Palmares. Além da Praça do Quilombo existente em nossa cidade, temos outros pontos turísticos muito importantes. Vale a pena fazer uma visita e conhecer.

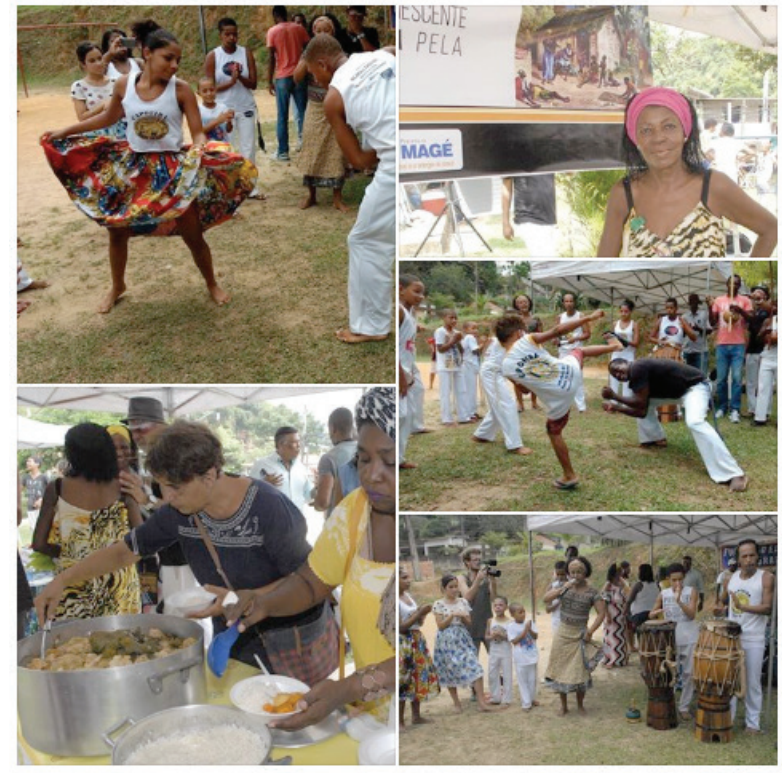

Fonte: Grupo disciplina Informática na Educação $(16 / 04 / 2017)$.

A partir das diferentes ambiências apresentadas nas três publicações e das narrativas produzidas sobre elas, compreendemos as pluralidades de práticas cotidianas que são operacionalizadas nesses espaçostempos e por onde também acontecem intercâmbios entre saberes, lutas-resistências e manifestações culturais. Essas postagens podem ser caracterizadas como autorias criadoras (BACKS, 2012), porque produziram um conteúdo novo.

A partir da partilha de opiniões, de posicionamentos e das produções autorais dos cursistas, chegamos à noção de "práticas de autorias partilhadas", que é compreendida como uma ação de autorização do sujeito no fazer por si (autoria) e de compartilhar a autoria para um grupo (partilha). Essa prática possibilita cada um trocar "algo que sei e que criei" na rede de participantes da turma.

\section{TESSITURAS FINAIS}

Nesta pesquisa-formação na cibercultura atrelada à epistemologia da multirreferencialidade, buscamos compreender como os cursistas da disciplina de Informática na Educação do curso de Pedagogia Uerj/ Cederj/UAB produzem e tecem suas autorias em rede. Nosso objetivo na proposição da "Aula 3" era de ampliar o repertório do(a)s cursistas em relação ao espaçostempos formativos on-line. Para isso, solicitamos a produção de conteúdo autoral na interface cidade -redes digitais.

A partir da noção que emergiu de práticas de autorias partilhadas, que é um desdobramento da proposição da "Aula 3", consideramos relevante fazer algumas reflexões em relação a essa experiência de pesquisa:

A atividade proposta possibilitou e oportunizou a vivência de tessituras de práticas curriculares dentrofora do ambiente Moodle, que é o ambiente institucional do curso;

A partilha da autoria com a turma foi importante para a promoção da interatividade e da colaboração em sala de aula, fazendo com que os participantes atuassem uns com os outros de maneira horizontal;

Habitar os espaços da cidade a partir de práticas educativas, como expostas pelos cursistas nas publicações anteriormente, favoreceu o enriquecimento da memória local, suas práticas e os sentidos que ali são produzidos por seus habitantes.

Por fim, ressaltamos a necessidade de lançar mão de práticas que possibilitem a autoria, a partilha e a produção do conhecimento em rede, aproveitando múltiplos meios, interfaces, dispositivos móveis e aplicativos disponíveis. 


\section{REFERÊNCIAS}

ARDOINO, Jacques. Para uma pedagogia socialista. Brasília: PLANO, 2003.

ARDOINO, Jacques. Pensar a Multirreferencialidade. In: MACEDO, Roberto Sidnei;

BARBOSA, Joaquim; BORBA, Sergio. (Org.). Jacques

Ardoino \& Educação. Belo Horizonte: Autêntica, 2012. p.87-100.

BACKS, Luciana. As manifestações da autoria na formação do educador em espaços digitais virtuais. Revista de Educação, Ciência e Cultura, v.17, n.2, jul-dez. 2012. Acesso em: 23 abr. 2017. Disponível em: <http://www.revistas.unilasalle.edu.br/index. php/Educacao/article/view/608/700 >. Acesso em: 22 abr. 2017

BERGER, Guy. A multirreferencialidade na Universidade de Paris Vincennes à Saint-Denis: o pensamento e a práxis de Jaques Adoirno. In: MACEDO, Roberto. S.; BARBOSA, Joaquim; BORBA, Sérgio. (Org.). Jacques Ardoino \& a Educação. Belo Horizonte: Autêntica, 2012. p.21-33.

CALVÃO, Leandro Dantas; PIMENTEL, Mariano; FUKS, Hugo. Do email ao Facebook: uma perspectiva evolucionista sobre os meios de conversação da internet. Rio de Janeiro: UNIRIO, 2014.

CARVAlHO, Felipe da Silva Ponte. Atos de Currículo na educação Online. Rio de Janeiro. 2015. Dissertação (Mestrado em educação) - ProPed/UERJ, 2015.

MACEDO, Roberto Sidnei. Atos de currículo e autonomia pedagógica: o socioconstrucionismo curricular em perspectiva. Petropólis, RJ: Vozes, 2013.
NÓVOA, António. Currículo e docência: a pessoa, a partilha, a prudência. Texto da palestra proferida no $1^{\circ}$ Colóquio Internacional de Políticas Curriculares, no dia 13 de novembro de 2003.

O PROJETO Naves do Conhecimento. Disponível em <http://navedoconhecimento.rio/\#nave >. Acesso em: 21 abr. 2017.

SANTOS, Edméa Oliveira. Pesquisa com a mobilidade ubíqua em redes sociais da internet: um case com o Twitter. Revista Com Ciência, online, 2012. Disponível em: <http://www.comciencia.br/comciencia/ handler.php?section=8\&edicao=74\&id=932 $>$. Acesso em: 22 abr. 2017.

\section{SANTOS, Edméa Oliveira. A pesquisa-formação na} cibercultura. Santo Tirso: Whitebooks, 2014.

SANTOS, Edméa Oliveira; CARVALHO, Felipe da Silva Ponte; PIMENTEL, Mariano. Mediação docente online para colaboração: notas de uma pesquisa-formação na cibercultura. ETD- Educação Temática Digital, Campinas-SP, v.18, n.2, p.23-42, jan-abr. 2016. Disponível em: <http://periodicos.sbu.unicamp.br/ojs/ index.php/etd/article/view/8640749/12238>. Acesso em: 25 maio 2016.

\section{SILVA, Marco. Formação de professores para a do-}

cência online. Braga: Universidade do Minho, 2009a. Disponivel em: <http://www.educacion.udc.es/grupos/gipdae/congreso/Xcongreso/pdfs/cc/cc2.pdf>. Acesso em: 25 maio 2016.

SANTOS, Edméa Oliveira. 0 desenho didático interativo na educação online. Revista Iberoamericana de Educación, n.49, p.267-287, 2009b. 
2 Doutorando em Educação pelo ProPed/UERJ; Membro do Grupo de Pesquisa Docência e Cibercultura. Orcid: http://orcid.org/0000-00017398-6171 E-mail: felipesilvaponte@gmail.com 